\title{
URBAN SPACE AND THE USES OF CULTURE
}

\section{Lisanne Gibson and Deborah Stevenson}

This special issue of the International Journal of Cultural Policy contributes to the discussion about the increasingly high-profile nature of cultural programs in inner-city urban regeneration initiatives. Whether these initiatives come under the rubrics of "creative industries", "cultural planning" or "cultural development", they have at their core a nexus between urban planning and cultural programming. The logic of this nexus is to ensure urban development facilitates the possibilities for community and citizenly social democratic participation; culture is thought to be an ideal tool for ensuring both diverse community representation and participation. However, to what extent are the cultural components of such urban regeneration schemes window dressing for middle-class cultural consumption, or are there real social and cultural benefits for those publics (and practitioners) who, although being priced out of many of the leisure, cultural and residential facilities provided, nevertheless flock to its spaces?

A selection of American, Australian, British and Canadian newspaper articles clipped over the last two years demonstrate the general acceptance of the "just add local culture and stir" school of thought. "Cool cities may defy planning: Leaders believe new image could boost state economy" (Singer 2003, p. 1) - for the Governor of Michigan, cafes, hip clubs, street vendors and loft homes are the winning formula for the attraction of the "creative class". "Mid-sized cities get hip to attract young professionals" (Nasser 2003, p. 1) reports that in Cincinnati "young professionals ... want to be part of the city's makeover" and first to go will be the pig sculptures in the city's downtown "which recall Cincinnati's golden era as a pork-processing center". "Can the arts cash in on cities' creativity buzz?"(Taylor 2003, p. 1)“the Canadian arts community has caught a whiff of the urban-renewal agenda and is hot on the scent". "Regeneration sexy? It is now" (Weaver 2001, p. 1) documents "concerns that an urban renaissance will lead to a form of social cleansing in British cities, of the kind that has occurred in New York under ... Republican mayor Rudolph Giuliani". "Can culture save us?' (Becket 2003, p. 1) discusses the massive investment in cultural regeneration in Newcastle and Gateshead in the North East of England. In "Not just a place to live, but a place to work" (Macken 2002, p. 22) it was lifestyle, "not the exchange rate" that "brought one entrepreneur to Sydney". We could go on, our newspaper clipping folders are overflowing with articles espousing the miracle of culturally led regeneration or development for cities large and small or for specific places within cities, including former (often waterfront) industrial sites or declining city centres.

Over the last twenty years, one of the central developments in the local governance of urban spaces and populations is the general acceptance of the notion that provision of access to, and consumption of, "cultural" resources is a central plank in successful urban development strategies. Indeed, as the above newspaper article titles demonstrate, cultural policies and programs increasingly are being seen as the antidotes to an ever-broadening range of social, economic and political problems. Most recently, "cultural planning" has been hailed as essential to the formation of an economically successful city, especially one that expects to be competitive in a global network of "creative cities" (Landry 2000; Florida 2002). 
In the United States, there has for some time been a critical engagement with cultural programs that are designed to be part of urban planning schemas that attempt to interact "holistically" with the everyday living needs of local communities (Zukin 1995; Deutsche 1998). In Australia and Britain, the critical discussion is only just beginning (Evans 2001; Stevenson 2003). As (predominantly British) consultants develop ever larger international consultancies marketing the "Temple Bar Effect" or the "Glasgow Model" to cities as diverse as Durham in Britain, Adelaide in Australia and Johannesburg in South Africa, the "revealed" truth of these models, and their almost unquestioning replication, is of concern. What is of most concern is the lack of rigorous research done on the cultural, economic, political and social short- and longterm effects of "cultural planning". What evidence is there, other than certain consultants "say so", that the massive public expenditure required for these redevelopment and re-imaging strategies actually produces outcomes that are in the public interest? Certainly Temple Bar is no longer the location of local micro-cultural businesses as it was before it was "culturally planned", ostensibly to benefit the local cultural industries. Its primary audience now is the international backpackers who go there for the overpriced beer and the "authentic" Irish food. Despite the mythological status of Glasgow as "proof" that cultural planning can cure all ills, there has to date been no research to investigate the cultural, economic, political and social effects of Glasgow's reconstruction of itself in the late 1980s and early 1990s as "a creative city". There is evidence that suggests that the benefits of this massive public expenditure were limited to international tourists and the socioeconomically privileged communities of Glasgow.

This special issue has been developed to contribute to the critical assessment and conversation on the relative merits and problems of cultural planning. The articles in this issue interrogate the nexus of urban planning and cultural programming from several directions, and use case studies drawn from a number of international contexts. Many of these articles point to a distinction in policy rhetoric and actual outcome; most of them point to the ways in which cultural planning has not lived up to its cultural, economic, social or political benchmarks. In this sense, we hope that this issue is a positive contribution for rethinking the nexus between urban planning and cultural programming. It is only through the close and rigorous interrogation of the assumptions underpinning this nexus, however it is articulated, that we will be able to develop achievable cultural policy recommendations that are able to deal with the complex cultural, economic, social and political factors involved in urban planning and development. This is a far cry from the "civic boosterism" that has informed much of the discussion of cultural planning to date.

The intentions of local government cultural planning is the topic of Darren Bayliss's article which surveys cultural planning and cultural development policies in local government authorities in Denmark. Bayliss discusses data drawn from his extensive survey of Danish urban local authorities to argue that social, rather than economic, objectives are the primary focus for Danish local authority cultural plans. He argues that more refinement is necessary for these strategies to be effective as social strategies. Illustrating the potential for local government to achieve social objectives by mediating between the cultural impacts of gentrification and urban development, Chris Gibson and Shane Homan discuss a local council program in Sydney that aims to respond to criticisms over the lack of spaces for live music. 
Inner city suburb live music venues in Sydney have declined and those that remain are subject to stringent noise legislation as a result of gentrification. Through this case study and their broader discussion of the politics of regulating live music venues, Gibson and Homan demonstrate some of the complexities of fostering cultural activity in specific local contexts.

In their discussion of inner-city studio complexes in Sydney and Melbourne, Australia and Toronto, Canada, Ben Goldsmith and Tom O'Regan analyse a particular nexus between an international cultural market and local cultural planning. In particular, they engage with the role of studio developments in the construction and marketing of an international "creative city" and their impact on local communities and creative industry markets. Similarly, the role of cultural planning in relation to urban development for major events such as Glasgow's year as a European "City of Culture" in 1990, the Olympics in Sydney in 2000 and the Universal Forum for Cultures in Barcelona, Spain in 2004 is the focus of Beatriz Garcia's article. In particular, Garcia argues that the relatively low status given to arts programs in relation to major events militates against their stated social objectives of involving local communities.

Recently, one of the most cited examples of successful "culture-led regeneration" is the redevelopment of the "Quayside" in Gateshead and Newcastle-upon-Tyne in the North East of England. Christopher Bailey, Steven Miles and Peter Stark trace the development of the massive commitment to "culture-led regeneration" in this region marked by significant economic and population decline. Reporting from early data being generated through their 10-year longitudinal research project on the cultural, economic and social impacts of the Newcastle/Gateshead Quayside development, they argue that "successful cultural regeneration is not about a trickle-down effect at all, but rather represents a counter-balance to broader processes of cultural globalization" through its potential to assert or reassert local identities.

Denise Meredyth, Scott Ewing and Julian Thomas assess the possibilities for cultural programs to affect local identities through their capacity to promote community participation and social cohesion. Their study of a "wired community" initiative in Melbourne, Australia finds that the scheme's educational outcomes may be more significant than its capacity to build community.

In concluding this issue, Deborah Stevenson provides a thorough critique of some of the aspirations informing cultural planning as it has come to be practiced in Australia and Britain. Her analysis reveals the close relations between the development of cultural planning discourses and the politics, personnel and institutions of "new" Labour. She argues that, as a result of these relations, the construction of citizenship adopted by cultural planning is one defined in terms of a capacity for economic participation. Thus cultural planning is "a tool for achieving social inclusion, an aim that is imagined principally in terms of economic accumulation". If cultural planning is constructed in this way, Stevenson's questions its utility for social justice outcomes.

The variety of programs, policies and strategies discussed in this special issue underscores the importance of the intersection between cultural programming and urban planning in developing "creative cities", "creative industries", "cultural regeneration" or attracting the "creative class". As this issue makes clear, the 
complexities of the cultural, economic, social and political implications of such programs are as multiple as their applications. It is clearly not simply a matter of "add culture and stir". We hope that that this issue contributes to a developing and critically engaged discussion on the potentials and complexities of the uses of culture in urban spaces.

\section{REFERENCES}

BECKET, A. (2003) 'Can culture save us?' The Guardian, 2 June.

DEUTSCHE, R. (1998) Evictions: Art and Spatial Politics, MIT Press, Cambridge, MA.

EVANS, G. (2001) Culture Planning: An Urban Renaissance? Routledge, London.

FLORIDA, R. (2002) The Rise of the Creative Class and How It's Transforming Work, Leisure, Community and Everyday Life, Basic Books, New York.

LANDRY, C. (2000) The Creative City: A Toolkit for Urban Innovators, Earthscan, London.

MACKEN, D. (2002) 'Not just a place to live, but a place to work', Weekend Australian Financial Review, 24-25 August.

NASSER, H. (2003) 'Mid-sized cities get hip to attract young professionals', USA Today, 16 October.

SINGER, C. (2003) "“Cool” cities may defy planning: Leaders believe new image could boost state economy', Detroit News, 9 October.

STEVENSON, D. (2003) Cities and Urban Cultures, Open University Press, Philadelphia, PA/Maidenhead.

TAYLOR, K. (2003) 'Can the arts cash in on cities' creativity buzz?' Globe and Mail, 22 October.

WEAVER, M. (2001) 'Regeneration sexy? It is now', The Guardian, 30 March.

ZUKIN, S. (1995) The Cultures of Cities, Blackwell, Oxford. 